\title{
IMPLEMENTASI SISTEM PEMUNGUTAN SUARA (VOTING) PADA EVENT ILEARNING IDOL DENGAN MENGGUNAKAN MEDIA RINFO FORM
}

\author{
M. Ifran Sanni ${ }^{1}$ \\ H. Haris ${ }^{2}$ \\ Siti Shelatul Aulia ${ }^{3}$ \\ ${ }^{1,2}$ Dosen AMIK Raharja \\ ${ }^{, 3}$ Mahasiswa STMIK Raharja \\ Jl. Jendral Sudirman No. 40, Modernland, Tangerang \\ ifran@ raharja.info ${ }^{1)}$, haris4cloud@gmail.com ${ }^{2)}$, shelatul@ raharja.info ${ }^{3)}$
}

\begin{abstract}
ABSTRAK
Voting adalah kegiatan yang sangat menentukan pada setiap perhelatan pemilihan, persoalan yang menjadi fokus perhatian bagi panitia penyelenggara pemilihan adalah bagaimana proses pemungutan suara dapat menjamin azas langsung, umum, bebas dan rahasia serta bagaimana hasil penghitungan suara dapat berlangsung jujur, transparan, dan dapat diakses oleh publik[1]. Salah satu kegiatan yang menggunakan proses voting yaitu iLearning iDol. iLearning iDol adalah ajang pencarian bakat mahasiswa iLearning Perguruan Tinggi Raharja untuk mengembangkan ilmu yang mereka punya dan di wujudkan lewat project yang berguna khususnya untuk Perguruan Tinggi. Pada Perguruan Tinggi Raharja untuk melakukan voting pada iLearning iDol masih menggunakan iLearning Media, hal ini dirasa kurang efektif. Untuk memenuhi hal tersebut maka terdapat sebuah sistem voting dengan menggunakan media RinfoForm. GoogleForm/RinfoForm merupakan alat yang berguna untuk membantu merencanakan acara, mengirim survey, memberikan mahasiswa kuis, atau mengumpulkan informasi yang mudah dengan cara yang efisien. Form juga dapat dihubungkan ke spreadsheet. Jika spreadsheet terkait dengan bentuk, tanggapan otomatis akan dikirimkan ke spreadsheet. Jika tidak, pengguna dapat melihat mereka di "Ringkasan Tanggapan" halaman dapat diakses dari menu Tanggapan. RinfoForm adalah salah satu fasilitas google.co.id yang sengaja disediakan untuk membuat survey atau kuesioner secara online.
\end{abstract}

Kata kunci : Voting, iLearningiDol, RinfoForm.

\begin{abstract}
Voting is an activity that is crucial in any event the election, the issue was the focus of attention for the organizing committee election is how the voting process can ensure the principle of direct, public, free and confidential and how the vote count results can be fair, transparent, and can be accessed by public[1]. One of the activities that use the voting process that is iLearningIdol. iLearningIdol is a talent show iLearningCollege studentProg to develop the knowledge they had and were embodied through a project that is particularly useful for Higher Education. In Higher Education Prog to vote on iLearningIdol still use iLearningMedia, it is less effective. To fulfill these conditions, there is a voting system using RinfoForm media. GoogleForm/RinfoForm is a useful tool to help plan the event, send a survey, giving students a quiz, or collecting information in an easy efficient way. Form may also be linked to a spreadsheet. If the spreadsheet associated with a form, an automatic response will be sent to the spreadsheet. If not, the user can see them in the "SummaryComments" page accessible from the menu response. RinfoForm is one which is deliberately google.co.id facilities provided to make online surveys or questionnaires.
\end{abstract}

Keywords : Voting, iLearningIdol, RinfoForm. 


\section{PENDAHULUAN}

Pemilihan Indonesian Idol, KDI, Idola Cilik dan berbagai kontes di tv bisa dilakukan secara real time online dengan melibatkan jutaan pemirsa di Indonesia hanya dengan perintah sangat singkat yaitu ketik reg spasi nama atau nomer lalu kirim ke nomer tujuan yang tertera di layar tv. Kalau itu bisa dilakukan untuk acara kontes mencari idola baru, maka tentu bisa juga diterapkan untuk pemilihan iLearning iDol karena mekanismenya tidak jauh berbeda. Yang justru menjadi pertanyaan apakah ada kemauan untuk itu? [2]

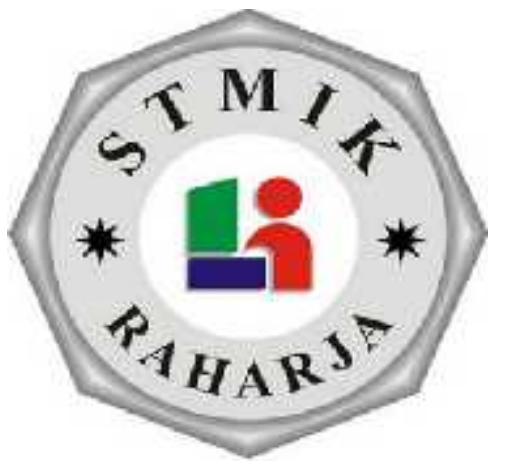

\section{Gambar 1.Logo Perguruan Tinggi Raharja}

Perguruan Tinggi Raharja merupakan salah satu organisasi yang bergerak dibidang pendidikan teknologi informasi, dan telah menerapkan sistem informasi tersebut. Untuk itu, Perguruan Tinggi Raharja terus menghadirkan inovasi baru dalam menciptakan sebuah sistem baru yang tentunya sangat menarik dan berguna dalam sistem pemungutan suara (voting) di Perguruan Tinggi Raharja. Voting merupakan kegiatan yang sangat menentukan pada setiap perhelatan pemilihan, persoalan yang menjadi fokus perhatian bagi panitia penyelenggara pemilihan adalah bagaimana proses pemungutan suara dapat menjamin azas langsung, umum, bebas dan rahasia serta bagaimana hasil penghitungan suara dapat berlangsung jujur, transparan, dan dapat diakses oleh publik[1]. Tidak kalah pentingnya adalah bagaimana proses pemungutan suara (voting) dapat menjamin azas langsung, umum, bebas dan rahasia serta bagaimana hasil penghitungan suara dapat berlangsung jujur, transparan, dapat diakses oleh publik. Voting adalah salah satu bentuk pencapaian konsensus yang apapun hasilnya mengikat semua anggota dalam suatu komunitas sosial. Suatu konsensus bisa dicapai melalui voting jika dialog antar mahasiswa menemui jalan buntu. Selama ini, pemungutan suara (voting) pada event iLearning iDol menggunakan media iMe (iLearning Media).

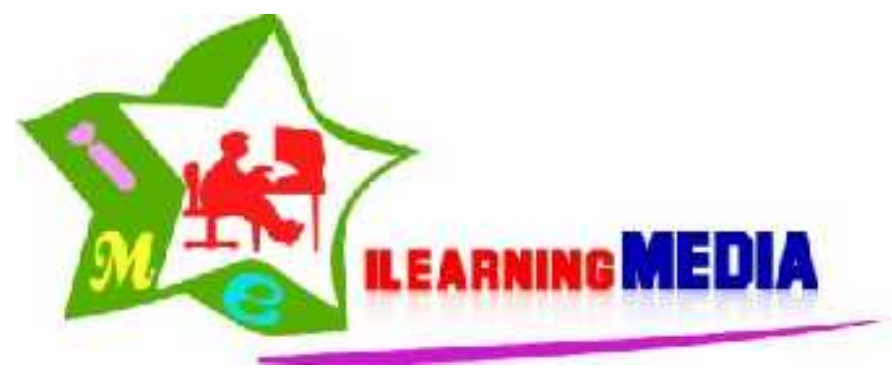

Gambar 2.Logo iMe (iLearning Media) 
iMe (iLearning Media) merupakan sebuah website iLearning yang dikemas secara khusus untuk kegiatan proses pembelajaran secara online. Secara garis besar, iMe dibuat untuk meningkatkan metode pembelajaran secara mandiri dan online. iMe dibuat untuk mahasiswa iLearning dan Dosen iLearning. Metode ini oleh banyak kalangan dinilai masih sangat konvensional di tengah kemajuan teknologi dan informasi, memiliki kelemahan dari aspek efisiensi dan efektifitas.

Sistem informasi diperlukan untuk mengolah data menjadi informasi, sehingga berbagai pihak yang membuat keputusan dapat menggunakan informasi tersebut untuk membuat keputusan yang baik. Informasi yang baik hanya dapat dihasilkan oleh sistem informasi yang baik. Sistem informasi yang baik adalah sistem informasi yang dengan sengaja dirancang untuk mengolah data menjadi informasi. Kini Perguruan Tinggi Raharja telah menerapkan inovasi baru dalam pengisian pemungutan suara (voting) pada iLearning iDol dengan menggunakan media RinfoForm. GoogleForm atau RinfoForm yang biasa di sebut pada Perguruan Tinggi Raharja merupakan alat yang berguna untuk membantu merencanakan acara, mengirim survey, memberikan mahasiswa atau orang lain kuis, atau mengumpulkan informasi yang mudah dengan cara yang efisien. Form juga dapat dihubungkan ke spreadsheet. Jika spreadsheet terkait dengan bentuk, tanggapan otomatis akan dikirimkan ke spreadsheet. Jika tidak, pengguna dapat melihat mereka di "Ringkasan Tanggapan" halaman dapat diakses dari menu Tanggapan. Tujuan yang dicapai dalam penelitian ini adalah untuk meningkatkan dan memaksimalkan sistem pemungutan suara (voting) dengan menggunakan media RinfoForm ini, sehingga mahasiswa/i dalam hal ini dapat dapat memilih dan mengetahui hasil voting dengan cepat, akurat dan terpercaya.

Permasalahan dalam pemungutan suara (voting) ini adalah mahasiswa harus memilih menggunakan media iMe (iLearning Media), kemudian mahasiswa harus comment pada iMe tersebut untuk memilih dengan mengketik nama peserta dan nomor peserta. Dan kebanyakan mahasiswa tidak ikut serta dalam memilih voting tersebut. Karena sistem pemungutan suara (voting) yang digunakan kurang efektif untuk mahasiswa maka digunakan sistem pemungutan suara (voting) dengan menggunakan media RinfoForm. Penyediaan RinfoForm diharapkan akan memberikan hasil pemungutan suara (voting) yang akurat, cepat dan terpercaya serta bisa mengurangi angka mahasiswa/i yang tidak memilih.

\section{PERMASALAHAN}

Pada dasarnya Perguruan Tinggi telah mempunyai banyak cara yang dapat digunakan untuk memaksimalkan sistem pemungutan suara (voting) ini, salah satu contohnya yaitu dengan mengadakan kuesioner maupun survey yang dilakukan. Namun tidak semua perguruan tinggi mempunyai standarisasi penilaian kinerja yang baik, dalam hal ini terdapat 4 (empat) permasalahan yang ada pada sistem pemungutan suara (voting) permasalahannya adalah sebagai berikut : permasalahan pertama voting yang masih menggunakan iMe (iLearning Media), permasalahan kedua voting masih kurang efektif dan kurang akurat, permasalahan ketiga tampilan voting kurang menarik, permasalahan keempat masih melakukan dan memerlukan rekap data dari voting yang telah dilakukan. 


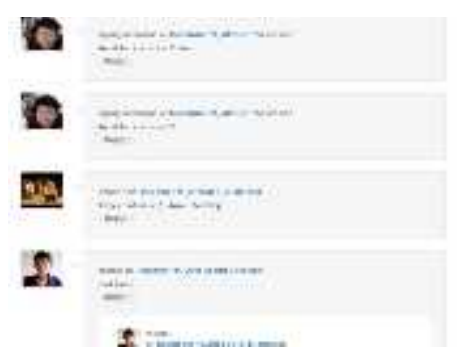

Gambar 3.Voting Menggunakan iMe (iLearning Media)

Gambar di atas menujukan permasalahan pertama yaitu mahasiswa menggunakan iMe (iLearning Media) sebagai media voting.

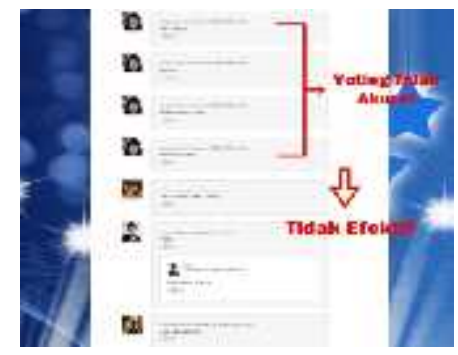

\section{Gambar 4.Voting Kurang Efektif dan Kurang Akurat}

Gambar di atas menujukan permasalahan kedua yaitu voting masih kurang efektif dan kurang akurat, karena masih banyak mahasiswa yang melakukan voting dan comment lebih dari yang di tentukan, maka dari itu voting di rasa kurang efektif dan kurang akurat.

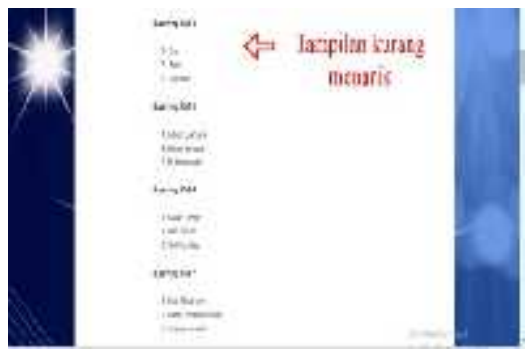

\section{Gambar 5.Tampilan Voting Kurang Menarik}

Gambar di atas menujukan permasalahan ketiga yaitu tampilan voting kurang menarik.

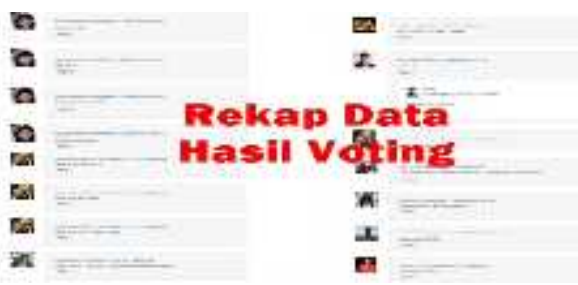

Gambar 6.Rekap Data Hasil Voting 
Gambar di atas menujukan permasalahan keempat masih melakukan dan memerlukan rekap data dari voting yang telah dilakukan.

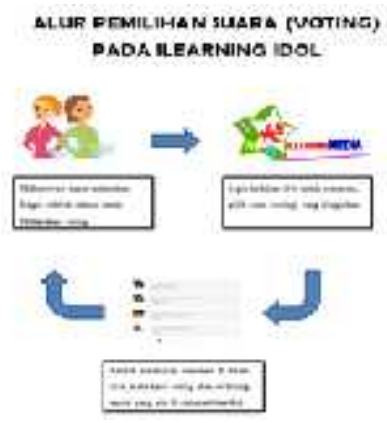

Gambar 7. Alur Melakukan Pemilihan Suara (Voting) pada iLearning iDol

Gambar di atas menunjukan Prosedur sistem yang sedang berjalan saat ini pada pemungutan suara (voting) iLearning iDol, mahasiswa harus memilih menggunakan media iMe (iLearning media), kemudian mahasiswa harus comment pada iMe (iLearning Media) tersebut untuk memilih dengan mengetik nama peserta dan nomor peserta. Namun masih banyak pula mahasiswa yang tidak ikut serta dalam voting tersebut dan ada juga mahasiswa yang melakukan voting dan comment lebih dari yang di tentukan, maka dari itu voting di rasa kurang efektif dan kurang akurat.

Tidak efektifnya pemungutan suara (voting) tersebut merugikan peserta karena banyak mahasiswa yang tidak ikut serta dalam pemungutan suara (voting), ada pula mahasiswa yang comment melebihi kapasitas yang di tentukan maka dari itu menyebabkan tidak akuratnya data, serta lambatnya dalam menghimpun hasil pemilihan suara (voting) pada iLearning iDol.

Rumusan masalah dalam penelitian ini adalah bagaimana implementasi sistem pemilihan suara (voting) pada event iLearning iDol dengan menggunakan media RinfoForm. Berdasarkan rumusan masalah yang telah di identifikasi maka tujuan yang ingin dihasilkan adalah meningkatkan dan memaksimalkan sistem pemilihan suara (voting) dengan menggunakan media RinfoFrom ini, sehingga mahasiswa/i dalam hal ini dapat dapat memilih dan mengetahui hasil voting dengan cepat, akurat dan terpercaya.

\section{LITERATURE REVIEW}

Literature review adalah bahan yang tertulis berupa buku, jurnal yang membahas tentang topik yang hendak diteliti ([Menurut Hermawan 2009:45]). Banyak penelitian yang sebelumnya dilakukan mengenai pemilihan suara (voting). Dalam upaya pembuatan voting ini perlu dilakukan studi pustaka sebagai salah satu dari penerapan metode penelitian yang akan dilakukan.Berikut ini adalah 3 penelitian yang telah dilakukan dan memiliki kolerasi yang searah dengan penelitian yang akan dibahas dalam Jurnal ini diantaranya :

1. Penelitian yang dilakukan oleh Rizqi Andhestria Adhi 1), Harjono2) pada tahun 2014 penelitian ini berjudul "Rancang Bangun Sistem Informasi E-Voting Berbasis SMS". 
Pada penelitian ini telah menghasilkan Sistem Informasi Peengingat Jadual Mengajar Dosen Berbasis Web dan SMS Gateway. Secara umum sistem SMS Gateway yang dipakai sama seperti sistem SMS pada pada handphone, namun dalam konteks ini yang menjadi user adalah Dosen Fakultas Teknik Informatika. Pada prinsipnya SMS Gateway adalah sebuah perangkat lunak yang diimplementasikan ke dalam komputer dan dengan memanfaatkan teknologi seluler yang diintegrasikan, guna mendistribusikan pesan yang dihasilkan lewat sistem informasi melalui media SMS yang ditangani oleh jaringan seluler.[1]

2. Penelitian yang dilakukan oleh Edi Priyono, Fereshti Nurdiana Dihan pada tahun 2011 penelitian ini berjudul "E-VOTING: URGENSI TRANSPARANSI DAN AKUNTABILITAS". Pada penelitian ini telah menunjukan bahwa aspek pertimbangan utama yang mendasari penerapan e-voting yaitu adanya sejumlah manfaat. Selain itu, era perkembangan teknologi informasi dan kondisi melek internet di semua negara sangatlah memungkinkan adopsi e-voting. Indonesia dengan kondisi geografis dan predikat sebagai negara kepulauan sangat berkepentingan untuk menerapkan evoting, tidak hanya bagi pemilihan legislatif dan pemilihan Presiden, tetapi juga untuk pelaksanaan pemilukada. Meskipun demikian, ancaman terhadap aspek keamanan tetap harus menjadi prioritas. [2]

3. Penelitian yang dilakukan oleh Nani Purwati Amik BSI Yogyakarta pada tahun 2015 penelitian ini berjudul "Perancangan Sistem E-Voting Untuk Pemilihan Kepala Daerah (Pilkada)". Pada penelitian ini telah menghasilkan Aplikasi e-voting yang dibangun mengurangi permasalahan proses percetakan suara karena suara yang didapat dalam bentuk data yang langsung bisa diberikan pada saat pemungutan suara.[3]

4. Penelitian yang dilakukan oleh Haryati, Kusworo Adi , Suryono pada tahun 2014 penelitian ini berjudul "Sistem Pemungutan Suara Elektronik Menggunakan Model Poll Site E-Voting ". Pada penelitian ini telah menghasilkan Sistem pemungutan suara yang diimplementasikan dalam bentuk pemungutan suara elektronik (e-voting). Sistem poll site e-voting yang dikembangkan pada penelitian ini memiliki prosedur dan tampilan yang user friendly bagi pemilih dan bagi KPU sebagai penyelenggara pemilihan umum. Sistem dapat menampikan hasil dari pemungutan suara dan informasi lainnya yang dibutuhkan sesaat setelah proses pemungutan suara selesai. Sistem poll site e-voting ini diharapkan mempunyai peluang yang baik serta tingkat resiko yang rendah untuk diterapkan di Indonesia.[4]

5. Penelitian yang dilakukan oleh Agus Qomaruddin Munir1), Evrita Lusiana Utari2) pada tahun 2016 penelitian ini berjudul "PEMANFAATAN E-KTP UNTUK PROSES PEMUNGUTAN SUARA PEMILIHAN UMUM DI INDONESIA MENGGUNAKAN SISTEM E-VOTE". Pada penelitian ini telah menghasilkan Konsep desain e-vote interaksi dapat diterapkan dalam proses pemilihan presiden ataupun kepala daerah dengan memperhatikan faktor-faktor berupa integrity, confidentiality dan availability dalam proses vote pada sistem. 2. Konsep desain sistem e-vote dapat membantu pemenuhan kriteria keberhasilan pemilu pilkada ataupun pilpres, yaitu dengan meningkatkan partisipasi massa, meningkatkan kedekatan antara massa dan calon pemilih. 3. Mempermudah dalam perhitungan hasil pemilihan, dan menciptakan pemilu yang LUBER dan JURDIL.[5] 
6. Penelitian yang dilakukan oleh Tohari Ahmad1), Royyana M. Ijtihadie2), Afrian Wicaksono3) pada tahun 2014 penelitian ini berjudul "PENGEMBANGAN SISTEM OTENTIKASI PADA E-VOTING MENGGUNAKAN NFC'. Pada penelitian ini telah menghasilkan teknologi NFC digunakan sebagai alternatif dalam proses otentikasi. Sebagai input, digunakan telepon pintar dan e-KTP, yang masing-masing mempunyai karakteristik tersendiri. Uji coba yang telah dilakukan menunjukkan bahwa proses otentikasi beberapa pemilih secara bersamaan meningkatkan relatif kecil waktu yang diperlukan. Demikian juga, pertambahan jumlah pemilih mempunyai sedikit pengaruh terhadap waktu yang diperlukan.[6]

7. Penelitian yang dilakukan oleh M. Ali Zaenal. A, Muhammad Akbar, Rusmin Syafari, pada tahun 2012 penelitian ini berjudul "ANALISIS DAN PERANCANGAN SISTEM PENGAMANAN E-VOTING BERBASIS WAP PEMILIHAN KETUA ORGANISASI KEMAHASISWAAN DI UNIVERSITAS BINA DARMA". Pada penelitian ini telah menghasilkan sebuah aplikasi yang memiliki akses on-line 24 jam penuh. Pada aplikasi perancangan sistem pengamana $e$-voting berbasis WAP (Wireless Aplication Protocol) pemilihan ketua organisasi ini, dimana mahasiswa atau anggota yang akan melakukan pemilihan dapat memilih dan melihat hasil pemilihan secara langsung. Jadi pemilih bisa mengetahui siapa yang paling banyak dipilih.[7]

Dilihat dari tujuh literature review yang telah dilakukan, maka diambil kesimpulan adanya kesamaan antara tulisan yang dikutip dengan penelitian yang dibuat ini, telah banyak penelitian mengenai voting menggunakan berbagai macam cara untuk meningkatkan metode pemilihan suara (voting). Karena Perguruan Tinggi Raharja voting yang diterapkan masih kurang efektif dengan meggunakan iMe (iLearning Media) maka dari itu penulis melakukan penelitian tentang voting menggunakan media RinfoFrom untuk meningkatkan fasilitas kampus pada pemilihan suara (voting). Oleh karena itu, untuk menindaklanjuti penelitian sebelumnya seperti yang dikemukakan diatas, maka dilakukan penelitian untuk "Implementasi Sistem Pemungutan Suara (Voting) pada Event iLearning iDol menggunakan Media RinfoForm" agar dapat meningkatkan sistem pemungutan suara (voting) sebelumnya agar lebih memudahkan mahasiswa dalam melakukan voting pada iLearning iDol.

\section{PEMECAHAN MASALAH}

Untuk mengatasi berbagai masalah tersebut, maka diperlukan sebuah sistem yang efektif dan efisien dalam melakukan pemungutan suara (voting). Dari rumusan masalah tersebut menghasilkan 1 pemecahan masalah yaitu dengan adanya media RinfoFrom maka diharapkan sistem pemungutan suara (voting) yang dilakukan secara online dengan menggunakan kuesioner, mahasiswa tidak perlu memilih suara (voting) menggunakan media iMe, dan mahasiswa juga tidak perlu melakukan comment pada iMe tersebut untuk memilih dengan mengetik nama peserta dan nomor peserta.

Berikut langkah langkah pemecahan masalah : 


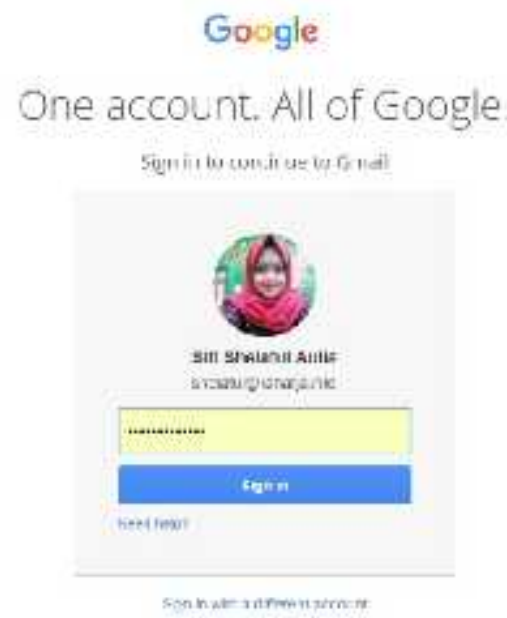

Gambar 8 . Tampilan Login SSO

Gambar di atas menjelaskan tampilan awal saat melakukan login menggunakan SSO (Single Sign Out) untuk memulai pembuatan form.

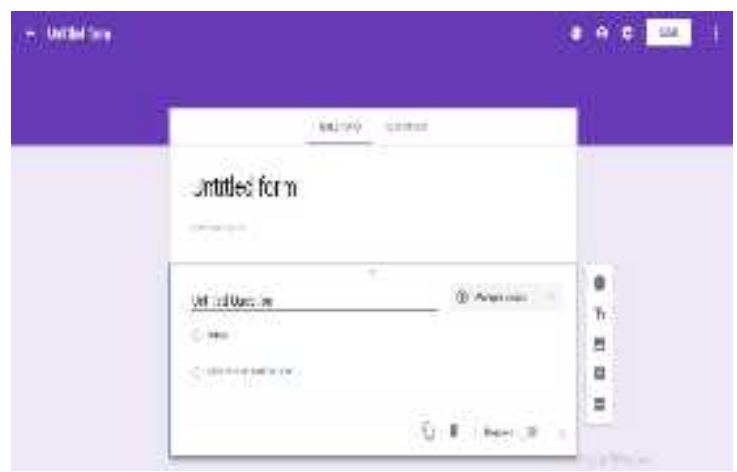

\section{Gambar 9. Tampilan Form Awal}

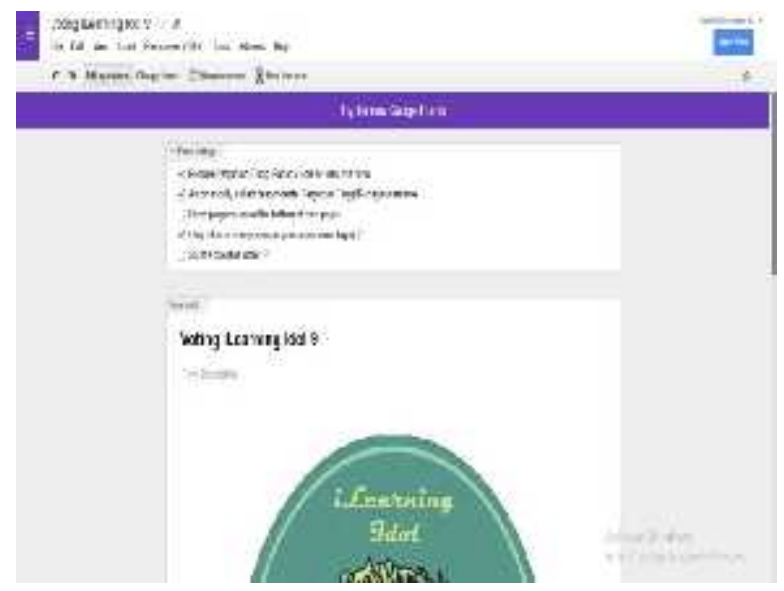

Gambar 10. Tampilan Proses Pembuatan Form 


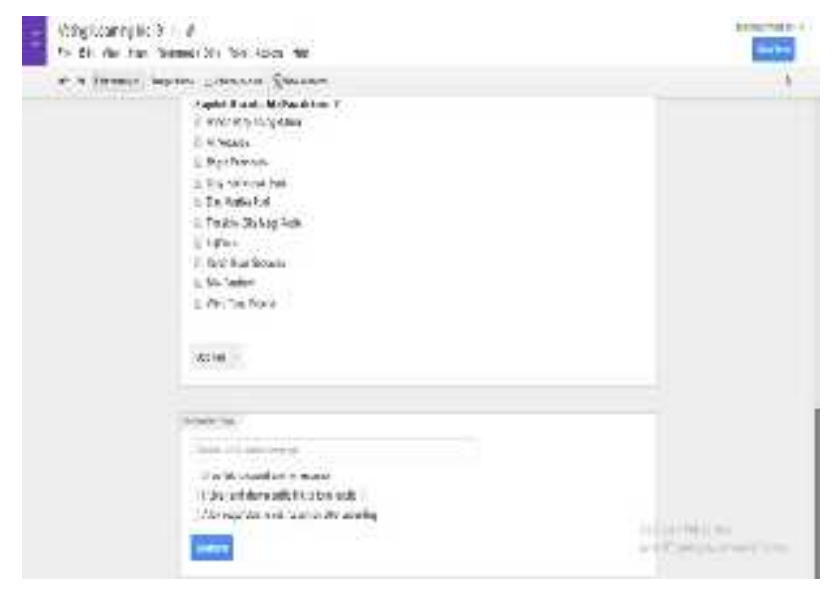

\section{Gambar 11. Tampilan Proses Pembuatan Form}

Gambar di atas menjelaskan tampilan awal pada saat melakukan pembuatan form dan melakukan pengisian antara lain : memasukan logo iLearning iDol dan memasukan nama peserta iLearning iDol untuk siap di pilih oleh mahasiswa. Kemudian send form untuk siap di sebar kepada mahasiswa.

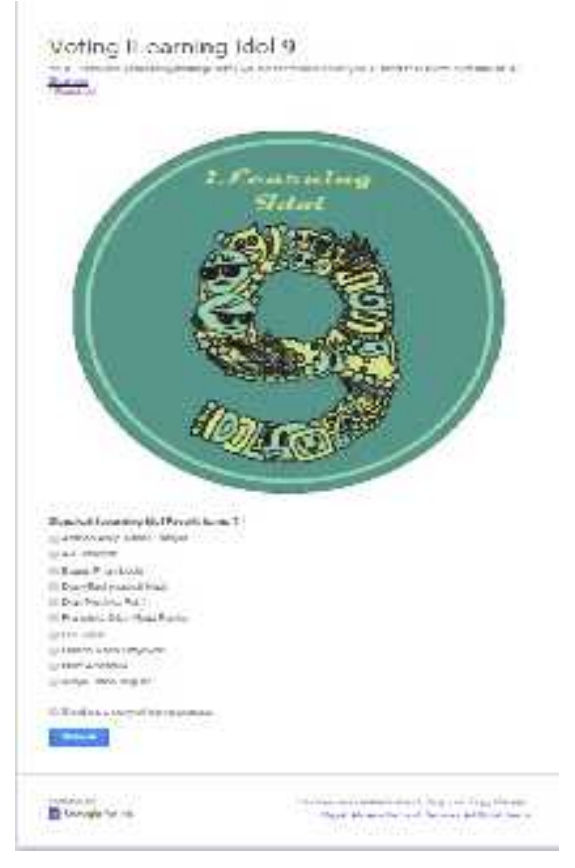

\section{Gambar 12. Tampilan Live Form}

Gambar di atas menjelaskan tampilan live form, untuk dapat di isi oleh mahasiswa . 


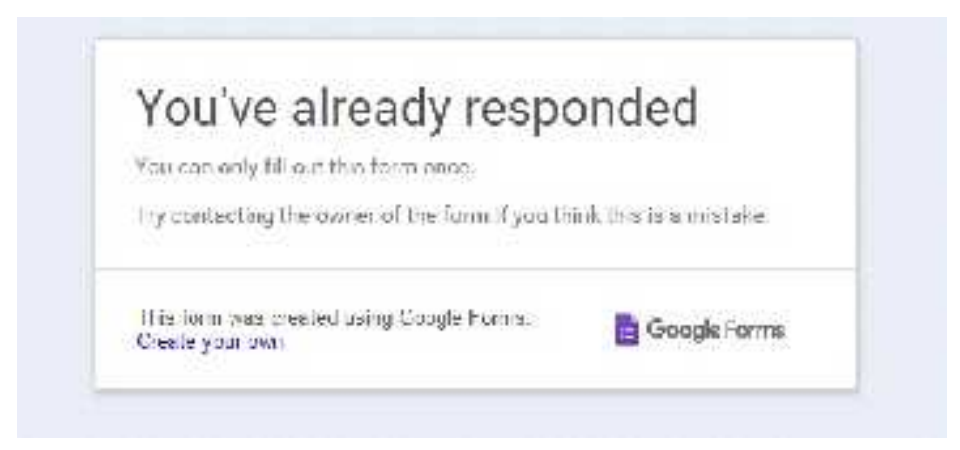

Gambar 13. Tampilan Responded

Gambar di atas menjelaskan tampilan responded setelah mahasiswa melakukan pengisian pada form, akan muncul tampilan seperti gambar di atas.

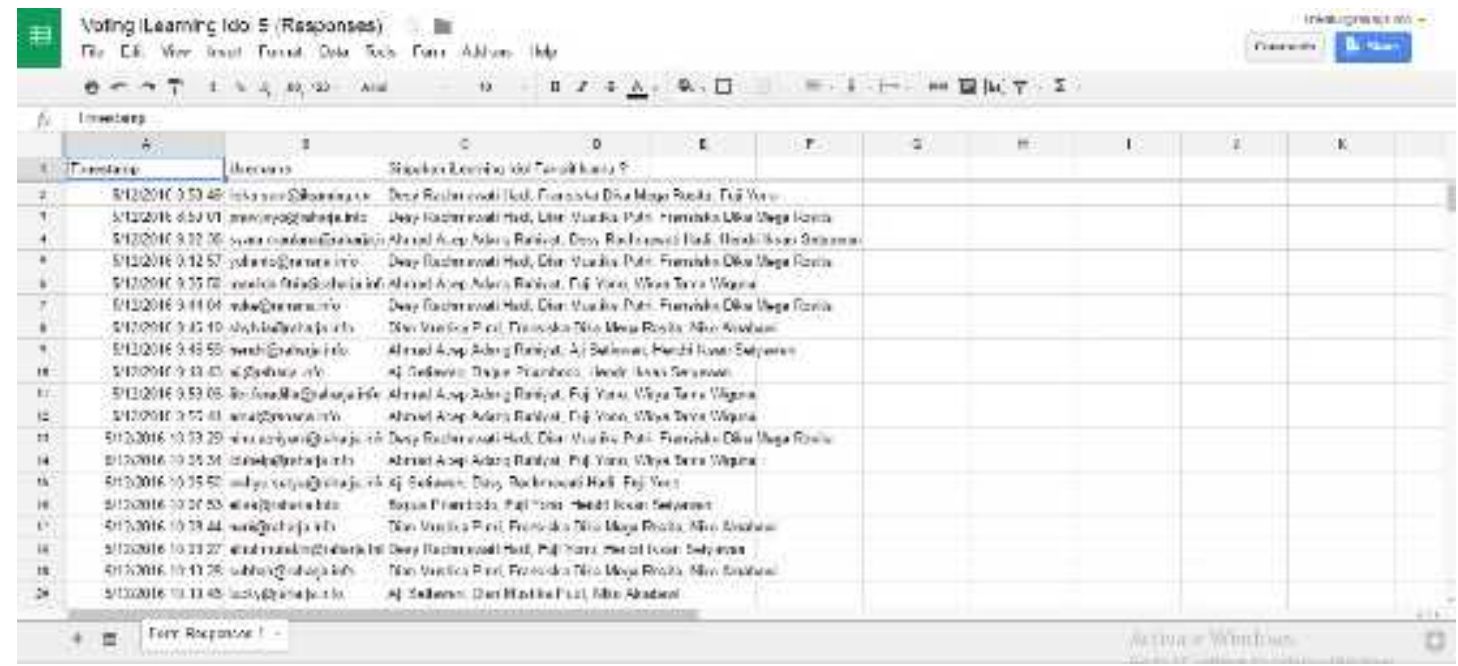

\section{Gambar 14. Tampilan View Responses}

Gambar di atas menunjukan tampilan view responses, setelah mahasiswa melakukan voting maka hasil nya akan langsung keluar melalui RinfoSheets. 

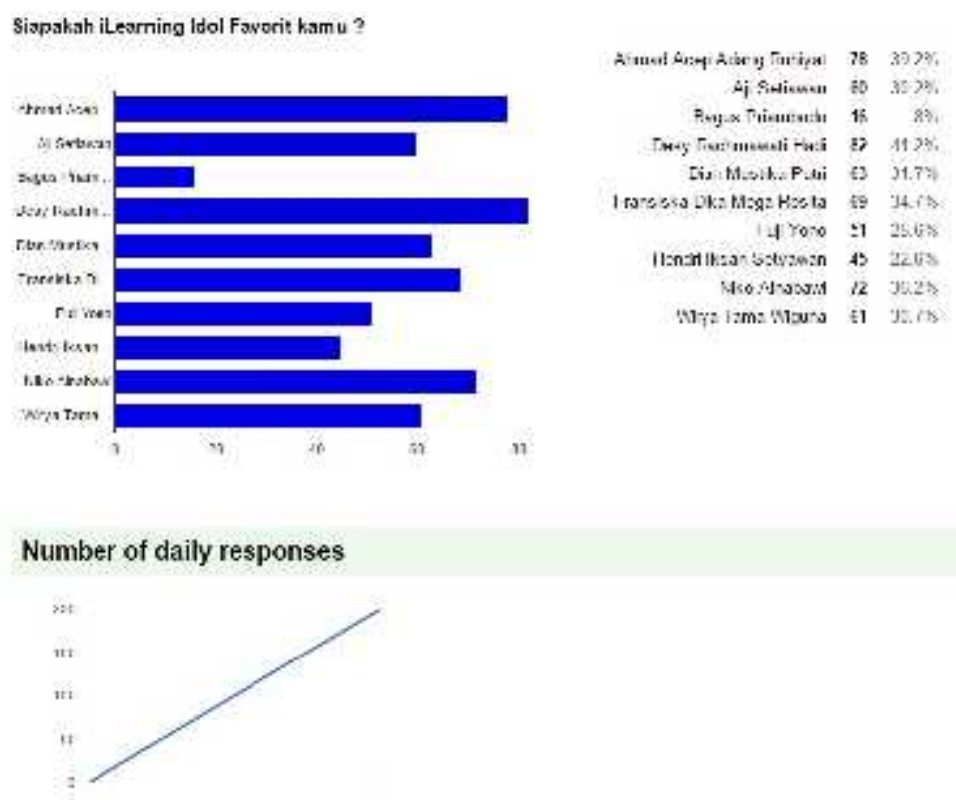

\section{Gambar 15. Grafik Pencapaian}

Gambar di atas menunjukan tampilan view responses berupa diagram. Dengan ada nya RinfoForm ini terbukti bahwa RinfoForm ini menghasilkan pemungutan suara (voting) yang akurat, cepat dan terpercaya serta hasilnya pun terbilang banyak yang memilih di bandingkan dengan yang sebelumnya secara manual dan yang memilihnya pun tidak semua ikut serta. Tetapi dengan adanya RinfoForm ini yang ikut melakukan voting pun meningkat.

\section{Mind Mapping}

Mind mapping adalah cara mengembangkan kegiatan berpikir ke segala arah, menangkap berbagai pikiran dalam berbagai sudut. Mind mapping mengembangkan cara berpikir divergen dan berpikir kreatif. Mind mapping yang sering kita sebut dengan peta konsep adalah alat berpikir organisasional yang sangat hebat yang juga merupakan cara termudah untuk menempatkan informasi ke dalam otak dan mengambil informasi itu ketika dibutuhkan ([Tony Buzan , 2008:4])

Ditinjau dari segi waktu mind mapping juga dapat mengefisienkan penggunaan waktu dalam mempelajari suatu informasi. Hal ini utamanya disebabkan karena metode ini dapat menyajikan gambaran menyeluruh atas suatu hal, dalam waktu yang lebih singkat. Dengan kata lain, Mind mapping mampu memangkas waktu belajar dengan mengubah pola pencatatan linear yang memakan waktu menjadi pencatatan yang efektif yang sekaligus langsung dapat dipahami oleh individu.

Pada metode Mind Mapping ini menghasilkan sebagai berikut yaitu penjelasan RinfoForm merupakan alat yang berguna untuk membantu merencanakan acara, mengirim survey, 
memberikan mahasiswa atau orang lain kuis, atau mengumpulkan informasi yang mudah dengan cara yang efisien. Form juga dapat dihubungkan ke spreadsheet. Jika spreadsheet terkait dengan bentuk, tanggapan otomatis akan dikirimkan ke spreadsheet. Jika tidak, pengguna dapat melihat mereka di "Ringkasan Tanggapan" halaman dapat diakses dari menu Tanggapan. Tujuan RinfoForm untuk meningkatkan dan memaksimalkan sistem pemilihan suara (voting) dengan menggunakan media RinfoForm ini, sehingga mahasiswa/i dalam hal ini dapat dapat memilih dan mengetahui hasil voting dengan cepat, akurat dan terpercaya. Kelebihan RinfoForm yaitu memudahkan mahasiswa dalam melakukan voting, mahasiswa tidak perlu memilih suara (voting) menggunakan media iMe, dan mahasiswa juga tidak perlu melakukan comment pada iMe tersebut untuk memilih dengan mengketik nama peserta dan nomor peserta, dan voting menjadi lebih mudah, cepat, akurat, dan efisien. Kekurangan RinfoForm yaitu Masih ada mahasiswa yang belum ikut serta dalam melakukan pemilihan suara (voting) karena waktu yang di tentukan. User pada RinfoForm yaitu Admin, dan Mahasiswa. Lima point mind mapping tersebut diambil berdasarkan fakta yang sesungguhnya yang terjadi pada iLearning iDol hasil dari penelitian yang dilakukan oleh peneliti.

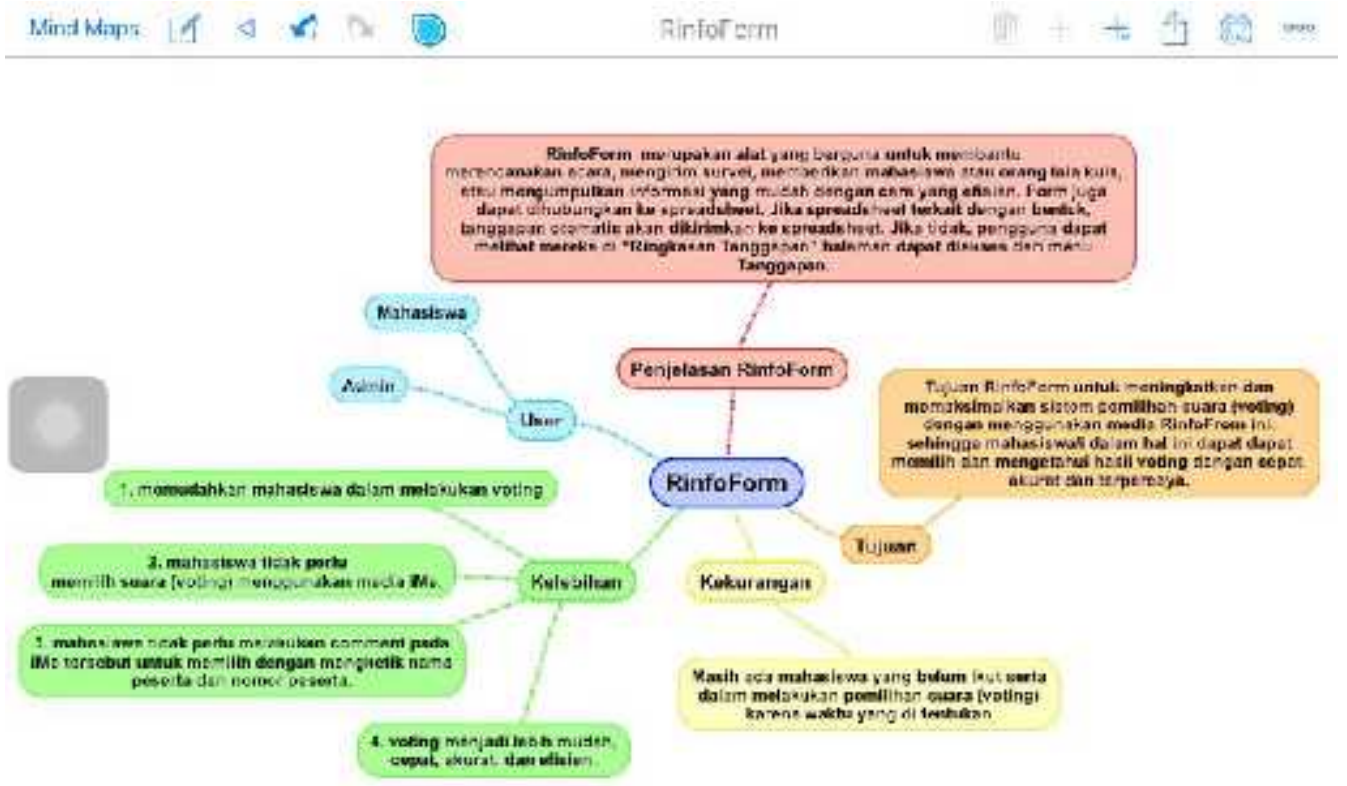

\section{Gambar 16. Mindmap RinfoForm}

\section{Flowchart Rancangan Aplikasi}

Flowchart adalah penggambaran secara grafik dari langkah-langkah dan urut-urutan prosedur dari suatu program ([Menurut Adelia 2011:116]). Flowchart program dalam pemecahan masalah merupakan keterangan yang lebih rinci tentang bagaimana setiap langkah program atau prosedur 
sesungguhnya akan dilaksakan. Flowchart ini menunjukan setiap langkah program atau prosedur dalam urutan yang tepat saat terjadi. Berikut flowchart sistem pemungutan suara (voting) pada event iLearning iDol sebagai berikut :

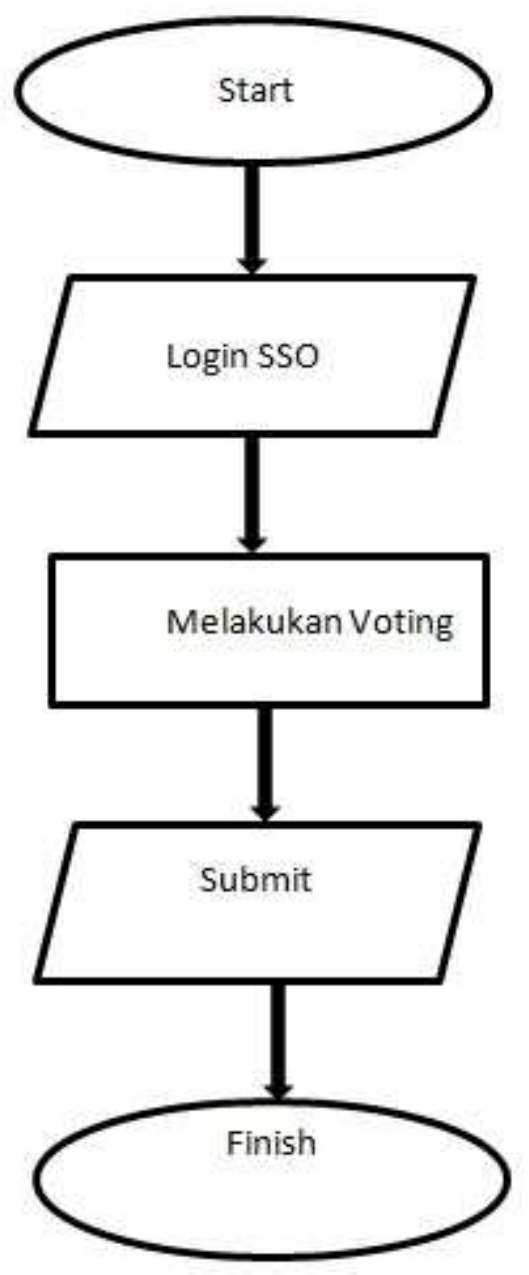

Gambar 17. Flowchart Sistem Pemungutan Suara (voting)

Gambar diatas menjelaskan proses berjalannya sistem pemungutan suara (voting) dengan menggunakan media RinfoForm:

1. Mahasiswa Login SSO

2. Mahasiswa melakukan voting

3. Mahasiswa submit 
Dari gambar di atas dapat dijabarkan bahwa hal yang pertama dilakukan oleh mahasiswa adalah melakukakan login SSO, kemudian mahasiswa melakukan voting dengan cara men-tab pilihan yang di pilih, setelah melakukan voting kemudian mahasiswa melakukan submit dan selesai.

\section{IMPLEMENTASI}

Untuk dapat membuat form pemilihan suara (voting), maka membutuhkan RinfoForm, berikut adalah tampilan form pemilihan suara (voting) yang telah di buat.

\section{A. Tampilan Awal Pembuatan Form}

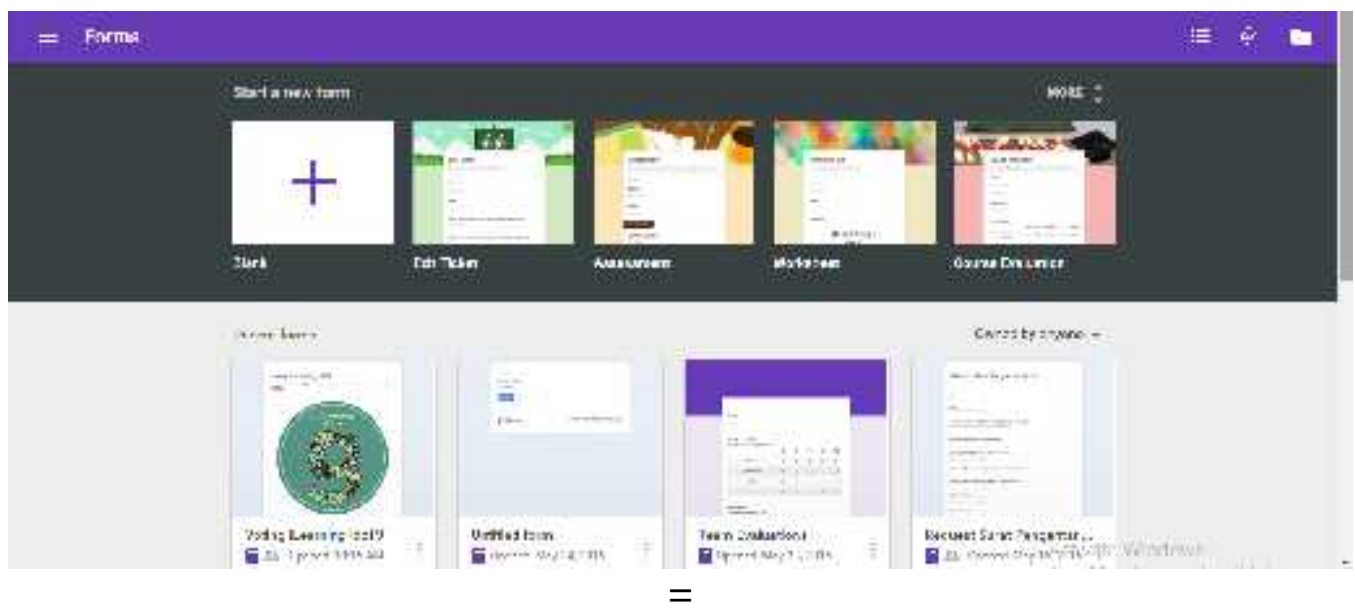

Gambar 18. Tampilan Awal Untuk Pembuatan Form

Tampak pada gambar di atas merupakan tampilan awal pada saat Admin melakukan pembuatan Form voting iLearning iDol.

\section{B. Proses Pembuatan Form}

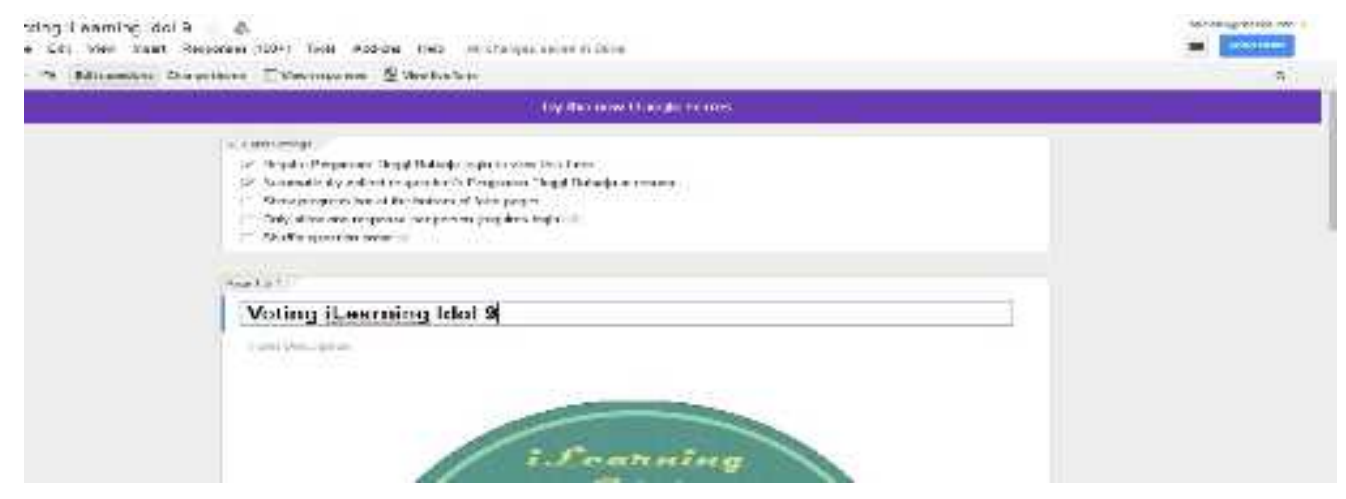

Gambar 19. Tampilan Pembuatan Form 
Gambar di atas merupakan tampilan pada saat Admin melakukan proses pembuatan form untuk di gunakan pada voting iLearning iDol, setelah selesai proses pembuatan form lalu klik send form.

\section{Tampilan Form Voting}

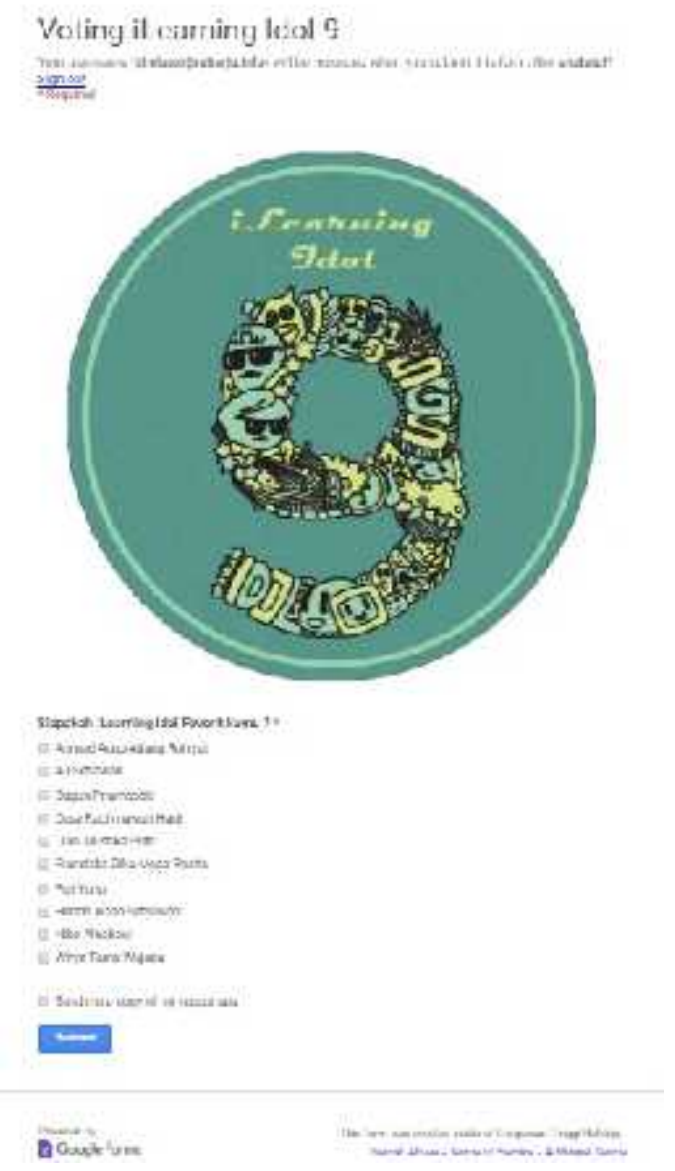

\section{Gambar 20. Tampilan Form Voting}

Gambar di atas merupakan tampilan form voting yang akan di isi oleh mahasiswa untuk melakukan voting dengan cara men-tab pilihan yang akan di pilih. Kemudian klik submit. 


\section{Tampilan Form Responded}

\section{You've already responded \\ You can only fill out this form once, \\ Iry contacting the owner of the form if you think this is s mistake. \\ This lo:m was creeted us ny Guogle Fomis. \\ Create your own \\ Google Forms}

\section{Gambar 21. Tampilan Form Responded}

Gambar di atas merupakan tampilan form responded yaitu tampilan setelah men-submit atau melakukan voting pada peserta iLearning iDol.

\section{E. Tampilan View Responses}

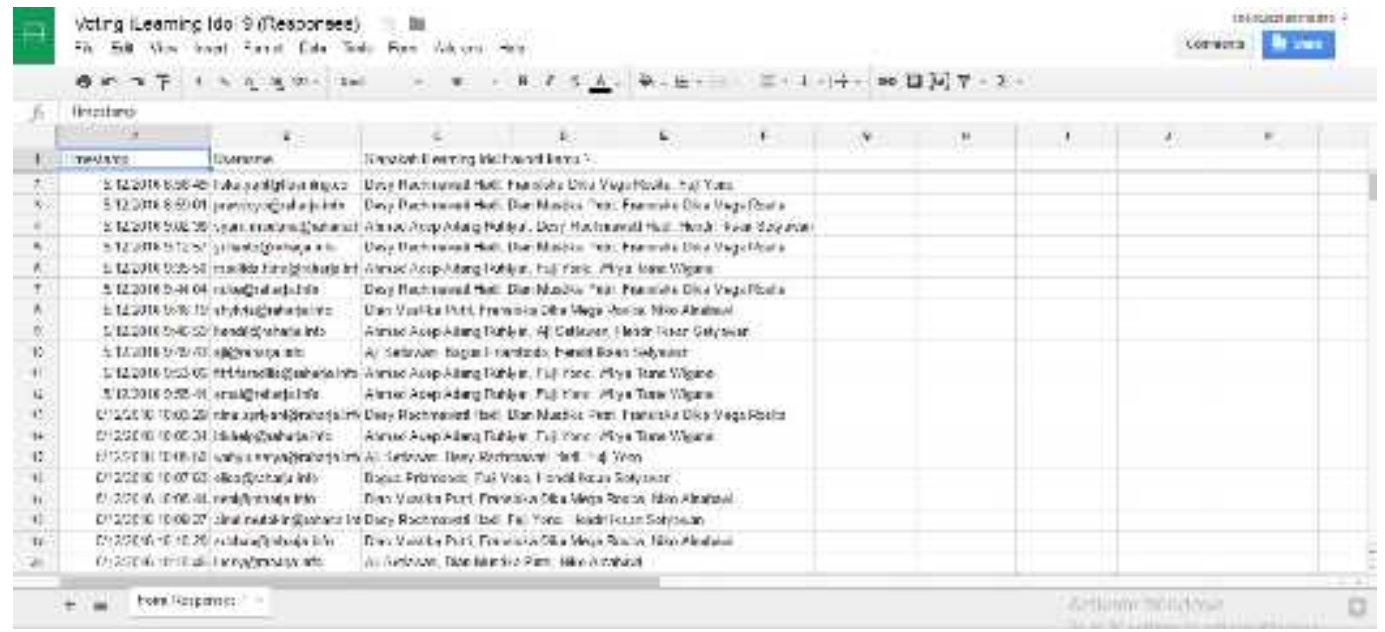

\section{Gambar 22. Tampilan View Responses}

Gambar di atas merupakan tampilan view responses yaitu hasil dari penghitungan voting yang berbentuk RinfoSheets. 


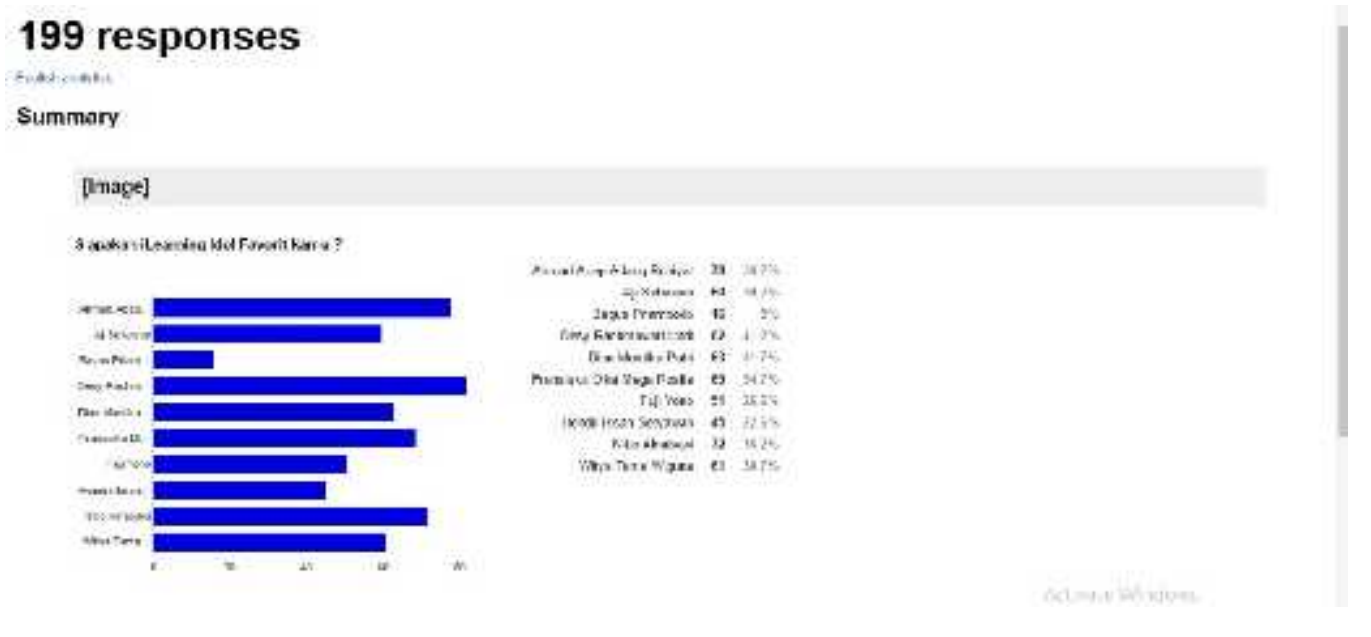

Gambar 23. Tampilan View Responses

Gambar di atas merupakan tampilan view responses yaitu hasil dari penghitungan voting yang berbentuk Diagram.

\section{KELEBIHAN RINFO FORM}

Memudahkan mahasiswa dalam melakukan voting. Mahasiswa langsung mengetahui hasil pemungutan suara (voting) tanpa menunggu lebih lama, Mahasiswa tidak perlu memilih suara (voting) menggunakan media iMe (iLearning Media), dan mahasiswa juga tidak perlu melakukan comment pada iMe (iLearning media) tersebut untuk memilih dengan mengetik nama peserta dan nomor peserta, voting menjadi lebih mudah, cepat, akurat, efisien dan terpercaya.

\section{KELEMAHAN RINFOFORM}

Masih ada mahasiswa yang belum ikut serta dalam melakukan pemungutan suara (voting) karena waktu yang di tentukan, harus menggunakan koneksi internet

\section{KESIMPULAN}

Dengan demikian dapat disimpulkan, penelitian ini menggunakan metode mind mapping. Dengan menggunakan media RinfoForm pada pemungutan suara (voting). Dengan adanya RinfoForm ini dapat meningkatkan dan memaksimalkan sistem pemungutan suara (voting), dan meminimalisir terjadinya ketidakikutsertaan pemungutan suara (voting) sehingga mahasiswa/i dalam hal ini dapat dapat memilih dan mengetahui hasil voting dengan cepat, akurat dan terpercaya. Dengan menggunakan RinfoForm ini sistem pemungutan suara (voting) menjadi lebih efisien, cepat, akurat dan terpercaya dibandingkan dengan menggunakan media iMe (iLearning media) yang diterapkan pada Perguruan Tinggi Raharja sebelumnya. Implementasi sistem pemungutan suara (voting) pada iLearning iDol dengan menggunakan media RinfoForm ini memudahkan mahasiswa dalam melakukan pemungutan suara (voting) dan mahasiswa 
langsung mengetahui hasil pemilihan suara (voting) tanpa menunggu lebih lama. Dengan adanya sistem pemungutan suara (voting) pada iLearning iDol dengan menggunakan media RinfoForm ini di harapkan dapat memberikan hasil pemungutan suara (voting) yang akurat, cepat dan terpercaya serta bisa mengurangi angka mahasiswa yang tidak memilih.

\section{DAFTAR PUSTAKA}

[1] Adhi, Rizqi Andhestria. "Rancang Bangun Sistem Informasi E-Voting Berbasis SMS (Developing E-Voting Information System SMS Based)."JUITA (JUrnal InformaTikA) 3.02 (2014).

[2] Edi, Priyono, and Nurdiana Dihan Fereshti. "E-VOTING: URGENSI TRANSPARANSI DAN AKUNTABILITAS." Telematika 7 (2011).

[3] Purwati, Nani. "perancangan Sistem E-Voting Untuk Pemilihan Kepala Daerah (PILKADA)." Bianglala Informatika 3.1 (2015).

[4] Haryati, Haryati, Kusworo Adi, and Suryono Suryono. "Sistem Pemungutan Suara Elektronik Menggunakan Model Poll Site E-Voting." JURNAL SISTEM INFORMASI BISNIS 1.1 (2014): 67-74.

[5] Munir, Agus Qomaruddin, and Evrita Lusiana Utari. "PEMANFAATAN E-KTP UNTUK PROSES PEMUNGUTAN SUARA PEMILIHAN UMUM DI INDONESIA MENGGUNAKAN SISTEM E-VOTE." SEMNASTEKNOMEDIA ONLINE 4.1 (2016): 2-4.

[6] Ahmad, Tohari, Royyana M. Ijtihadie, and Afrian Wicaksono. "PENGEMBANGAN SISTEM OTENTIKASI PADA E-VOTING MENGGUNAKAN NFC." SESINDO 2014 (2014).

[7] Zaenal, M. Ali, A. Akbar, and Rusmin Syafari. "ANALISIS DAN PERANCANGAN SISTEM PENGAMANAN E-VOTING BERBASIS WAP PEMILIHAN KETUA ORGANISASI KEMAHASISWAAN DI UNIVERSITAS BINA DARMA." JURNAL MAHASISWA TI S1 (2012). 